University of Nebraska - Lincoln

DigitalCommons@University of Nebraska - Lincoln

6-2014

\title{
Sex-Biased Gene Flow Among Elk in the Greater Yellowstone Ecosystem
}

\author{
Brian K. Hand \\ University Of Montana, brian.hand@umontana.edu \\ Shanyuan Chen \\ Universidade do Porto (CIBIO-UP) \\ Neil Anderson \\ Montana Department of Fish \\ Albano Beja-Pereira \\ Universidade do Porto (CIBIO-UP) \\ Paul C. Cross \\ Northern Rocky Mountain Science Center
}

See next page for additional authors

Follow this and additional works at: https://digitalcommons.unl.edu/usgsstaffpub

Part of the Geology Commons, Oceanography and Atmospheric Sciences and Meteorology Commons, Other Earth Sciences Commons, and the Other Environmental Sciences Commons

Hand, Brian K.; Chen, Shanyuan; Anderson, Neil; Beja-Pereira, Albano; Cross, Paul C.; Ebinger, Michael; Edwards, Hank; Garrott, Robert A.; Kardos, Marty D.; Kauffman, Matt; Landguth, Erin L.; Middleton, Arthur; Scurlock, Brandon; White, P.J.; Zager, Pete; Schwartz, Michael K.; and Luikart, Gordon, "Sex-Biased Gene Flow Among Elk in the Greater Yellowstone Ecosystem" (2014). USGS Staff -- Published Research. 1103. https://digitalcommons.unl.edu/usgsstaffpub/1103

This Article is brought to you for free and open access by the US Geological Survey at DigitalCommons@University of Nebraska - Lincoln. It has been accepted for inclusion in USGS Staff -- Published Research by an authorized administrator of DigitalCommons@University of Nebraska - Lincoln. 


\section{Authors}

Brian K. Hand, Shanyuan Chen, Neil Anderson, Albano Beja-Pereira, Paul C. Cross, Michael Ebinger, Hank Edwards, Robert A. Garrott, Marty D. Kardos, Matt Kauffman, Erin L. Landguth, Arthur Middleton, Brandon Scurlock, P.J. White, Pete Zager, Michael K. Schwartz, and Gordon Luikart 


\title{
Notes \\ Sex-Biased Gene Flow Among Elk in the Greater Yellowstone Ecosystem
}

Brian K. Hand,* Shanyuan Chen, Neil Anderson, Albano Beja-Pereira, Paul C. Cross, Michael Ebinger, Hank Edwards, Robert A. Garrott, Marty D. Kardos, Matt Kauffman, Erin L. Landguth, Arthur Middleton, Brandon Scurlock, P.J. White, Pete Zager, Michael K. Schwartz, and Gordon Luikart

\section{B.K. Hand, M.D. Kardos, G. Luikart, E.L. Landguth}

The University of Montana, Division of Biological Sciences, Missoula, Montana 59812

\section{B.K. Hand, M.D. Kardos}

Montana Ecology of Infectious Diseases Integrative Graduate Education and Research Traineeship Program (GERT), The University of Montana, Missoula, Montana 59812

\section{G. Luikart}

Flathead Lake Biological Station, Fish and Wildlife Genomics Group, The University of Montana, Polson, Montana 59860

\section{S. Chen, A. Beja-Pereira, G. Luikart}

Centro de Investigação em Biodiversidade e Recursos Genéticos, Universidade do Porto (CIBIO-UP), Campus Agrário de Vairão, 4485-661 Vairão, Portugal

\section{P.C. Cross}

U.S. Geological Survey, Northern Rocky Mountain Science Center, Bozeman, Montana 59715

\section{M.R. Ebinger, R.A. Garrott}

Department of Ecology, Montana State University, Bozeman, Montana 59715

\section{P.J. White}

National Park Service, Yellowstone National Park, Mammoth, Wyoming 82190

\section{H. Edwards}

Wyoming Game and Fish Department, Wildlife Disease Laboratory, Laramie, Wyoming 82070

\section{A. Middleton, M. Kauffman}

Wyoming Cooperative Fish and Wildlife Research Unit, Department of Zoology and Physiology, Laramie, Wyoming 82071

\section{M.K. Schwartz}

U.S. Department of Agriculture Forest Service, Rocky Mountain Research Station, Missoula, Montana 59801

\section{N.J. Anderson}

Montana Department of Fish, Wildlife, and Parks, Bozeman, Montana 59717

\section{P. Zager}

Idaho Department of Fish and Game, Lewiston, Idaho 83501

\section{B. Scurlock}

Wyoming Game and Fish Department, Pinedale, Wyoming 82941

\begin{abstract}
We quantified patterns of population genetic structure to help understand gene flow among elk populations across the Greater Yellowstone Ecosystem. We sequenced 596 base pairs of the mitochondrial control region of 380 elk from eight populations. Analysis revealed high mitochondrial DNA variation within populations, averaging 13.0 haplotypes with high mean gene diversity (0.85). The genetic differentiation among populations for mitochondrial DNA was relatively high $\left(F_{S T}=0.161 ; P=0.001\right)$ compared to genetic differentiation for nuclear microsatellite data $\left(F_{S T}=0.002\right.$; $P=0.332$ ), which suggested relatively low female gene flow among populations. The estimated ratio of male to female gene flow $\left(m_{m} / m_{f}=46\right)$ was among the highest we have seen reported for large mammals. Genetic distance (for mitochondrial DNA pairwise $F_{S T}$ ) was not significantly correlated with geographic (Euclidean) distance between
\end{abstract}


populations (Mantel's $r=0.274, P=0.168$ ). Large mitochondrial DNA genetic distances (e.g., $\left.F_{S T}>0.2\right)$ between some of the geographically closest populations $(<65 \mathrm{~km})$ suggested behavioral factors and/or landscape features might shape female gene flow patterns. Given the strong sex-biased gene flow, future research and conservation efforts should consider the sexes separately when modeling corridors of gene flow or predicting spread of maternally transmitted diseases. The growing availability of genetic data to compare male vs. female gene flow provides many exciting opportunities to explore the magnitude, causes, and implications of sex-biased gene flow likely to occur in many species.

Keywords: Cervus elephus; female philopatry; genetic population structure; Yellowstone National Park

Received: February 13, 2012; Accepted: December 11, 2013; Published Online Early: December 2013; Published: June 2014

Citation: Hand BK, Chen S, Anderson N, Beja-Pereira A, Cross PC, Ebinger M, Edwards MH, Garrott RA, Kardos MD, Kauffman M, Landgut EL, Middleton A, Scurlock B, White PJ, Zager P, Schwartz MK, and Luikart G. 2014. Sex-biased gene flow among elk in the greater Yellowstone ecosystem. Journal of Fish and Wildlife Management 5(1):124-132; e1944-687X. doi: 10.3996/022012-JFWM-017

Copyright: All material appearing in the Journal of Fish and Wildlife Management is in the public domain and may be reproduced or copied without permission unless specifically noted with the copyright symbol $\odot$. Citation of the source, as given above, is requested.

The findings and conclusions in this article are those of the author(s) and do not necessarily represent the views of the U.S. Fish and Wildlife Service.

* Corresponding author: brian.hand@umontana.edu

\section{Introduction}

The Greater Yellowstone Ecosystem (GYE) supports world-renowned populations of elk (Cervus elaphus) that provide significant visitor enjoyment and benefits to local economies through guiding, hunting, and ecotourism. Elk are the most numerous large mammal in the GYE $(N \sim 50,000)$ and have strong effects on other species including predators and scavengers. Elk influence ecosystem characteristics and processes such as soil fertility, and vegetation production and diversity (Toweill et al. 2002). Elk maternal gene flow (where gene flow is defined as the exchange of alleles between populations) is important to understand because female gene flow and physical movement influence genetic and demographic rescue, colonization rates, demographic vital rates, and the spread of certain diseases (Thorne et al. 1979; Martin et al. 2000; Tallmon et al. 2004).

The GYE is one of a few areas where elk were not extirpated in North America by the early 1900s due to overharvest, competition with livestock, and perhaps disease (Houston 1974). Elk have not been translocated into or within the GYE. These observations make the GYE among the best (and few remaining) locations to study natural population genetic structure and patterns of gene flow in elk (Houston 1974; Boyce and Hayden-Wing 1979; Polziehn and Strobeck 1998). The GYE stretches approximately $400 \mathrm{~km}$ north-south and $300 \mathrm{~km}$ eastwest, spanning portions of Idaho, Montana, and Wyoming with elevation ranges from 1,200 to 4,200 $\mathrm{m}$ for our study area (Figure 1).

Mitochondrial (mt) DNA is a useful marker for resolving maternal gene flow because it is a maternally inherited haploid marker with a single chromosome coming only from the mother whereas nuclear microsatellite DNA markers are biparentally inherited (with a single allele from each parent; Allendorf et al. 2013). Recent work from Hedrick et al. (2013) presents an equation to estimate the ratio of male to female gene flow from genetic distance estimates ( $F_{S T}$ calculated from mtDNA or microsatellites) using Wright's (1951) island model of gene flow. The equation is useful for studies in which markers for global gene flow for both sexes (e.g., microsatellites from nuclear DNA) and maternal gene flow (e.g., mitochondrial DNA) are available. Genetic distance estimates also allow for tests for patterns of genetic structure such as isolation by distance (e.g., genetic distance and geographic distance between populations are related such that genetic distance increases monotonically with geographic distance; Wright 1943) that can help managers understand patterns of gene flow.

We assessed maternal and overall gene flow patterns in elk by estimating the ratio of male to female gene flow using $F_{S T}$ values calculated using mtDNA from eight populations and microsatellite markers from a subset (three of the eight) of populations in the GYE. We then assessed the generality of our findings by comparing our ratios of gene flow in elk to other large mammals using published studies reporting the $F_{S T}$ for both maternal and overall genetic differentiation. Finally, we tested the hypothesis of isolation by distance in elk maternal genetic structure. From our results we suggest new and promising directions for future research in landscape genetics and sex-specific gene flow in elk and other species.

\section{Methods}

We collected samples of blood, tissue, or fecal pellets from 380 elk (223 females, 19 males, 138 unknown) in 


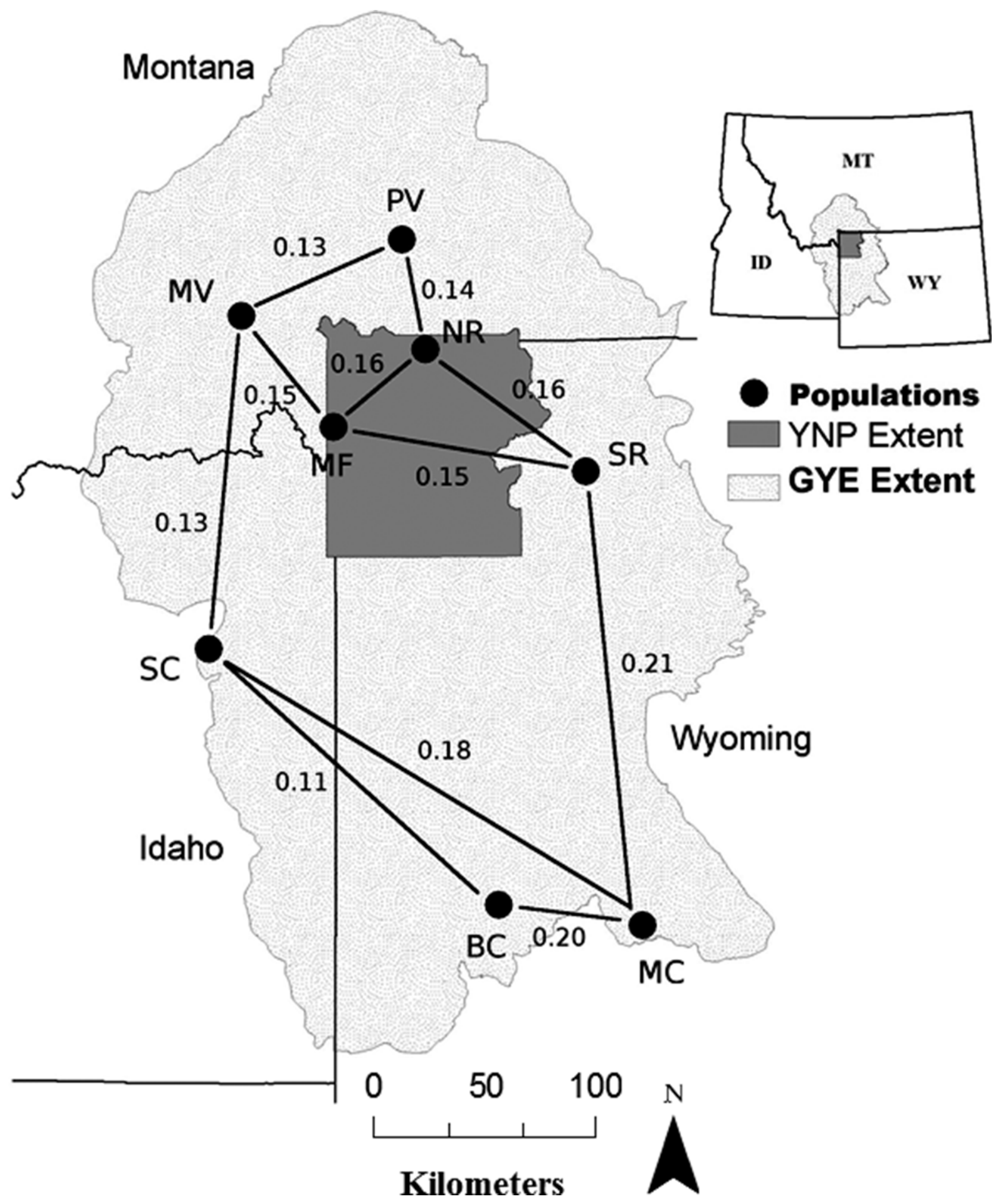

Figure 1. Map of the eight elk (Cervus elaphus) populations sampled from the Greater Yellowstone Ecosystem (GYE) during the years of 2005-2008. Populations here are defined as large groups of individuals from a geographic location where elk congregate, such as winter ranges with hundreds to thousands of elk. For example, the two southernmost populations are feeding grounds in Wyoming where elk are fed hay in winter to keep them away from cattle and private ranches. Yellowstone National Park (YNP) is shown in gray. Numbers on the lines are pairwise mtDNA $F_{S T}$ values for the populations connected by the lines. Population abbreviations are as follows: PV = Paradise Valley (Montana), MV = Madison Valley (Montana), NR = Northern Range (YNP), MF = Madison-Firehole (YNP), SR = Shoshone River (Wyoming), MC = Muddy Creek (Wyoming feeding ground), BC = Bench Corral (Wyoming feeding ground), and SC = Sand Creek (Idaho). 
Table 1. Microsatellite loci and polymerase chain reaction (PCR) conditions used in this study of three elk (Cervus elaphus) populations (Paradise Valley, Montana; Muddy Creek, Wyoming; and Northern Range, Yellowstone National Park, Wyoming) from the Greater Yellowstone Ecosystem from samples collected between the years of 2005 and 2008. Listed are the sets of loci coamplified together in each multiplex PCR, the observed range of allele lengths (in nucleotides) for each locus, PCR annealing temperatures, and the source reference for each locus (including prime sequences).

\begin{tabular}{|c|c|c|c|c|}
\hline Multiplex & Locus & Allele lengths & Annealing temperature & Locus reference \\
\hline \multirow[t]{3}{*}{ Mix A } & BM5004 & $130-140$ & $56^{\circ} \mathrm{C}$ & Bishop et al. (1994) \\
\hline & BM888 & 180-194 & & Bishop et al. (1994) \\
\hline & $\mathrm{BM} 1009^{\mathrm{a}}$ & $268-284$ & & Bishop et al. (1994) \\
\hline \multirow[t]{2}{*}{ Mix B } & BM4208 & $145-157$ & $56^{\circ} \mathrm{C}$ & Bishop et al. (1994) \\
\hline & FCB193 & $118-146$ & & Buchanan and Crawford (1992) \\
\hline \multirow[t]{2}{*}{ Mix C } & OarkP6 & $161-163$ & $54^{\circ} \mathrm{C}$ & Paterson and Crawford (2000) \\
\hline & RM006 & 123-139 & & Kossarek et al. (1993) \\
\hline Mix E & BM415 & $154-164$ & $50^{\circ} \mathrm{C}$ & Bishop et al. (1994) \\
\hline
\end{tabular}

a Amplified separately for fecal pellet (lower-quality) DNA samples.

eight populations in the GYE (Table 2; Figure 1). We sampled more females than males to precisely quantify maternal gene flow to help predict spread of maternally transmitted diseases, and because we expected males to show little structure and thus be less informative for gene flow studies (Hicks et al. 2007). In addition, we preferentially captured females captured for radio-collar studies. We collected samples $(n \approx 20)$ during multiple years (20052008) from four populations (Paradise Valley, Madison Valley, Northern Range, and Muddy Creek) to test for temporal stability of haplotype frequencies (Table 1).

We defined populations as large groups or collections of individuals from a location where elk congregate, such as winter ranges with hundreds to thousands of elk. All collection of samples occurred within a 4-yr time frame (one generation) to reduce potential intergenerational effects (e.g., on spatial $F_{S T}$ estimates). We collected blood or tissue from captured (Northern Range, Paradise Valley, and Madison-Firehole) or hunter-killed elk (Madison Valley, Shoshone River, Muddy Creek). We collected fecal pellets within 1-2 $\mathrm{h}$ after defecation in Sand Creek and Bench Corral and from 5 of 62 individuals from Muddy Creek (Figure 1). To prevent repeated sampling of the same individual, we only collected feces from individuals observed defecating, small groups (5-10) of individuals that were at least $0.5-1 \mathrm{~km}$ apart, or from individuals with distinctive natural marking or unique ear tags, or radio collars.

We isolated DNA from tissue and blood using the Qiagen QIAamp isolation kit (Chatsworth, California) and from feces using the QIAamp blood kit as described in Maudet et al. (2004). We conducted polymerase chain reaction (PCR) amplification on a 596-base pair fragment of the mtDNA control region using primers $275-294 \mathrm{~F}\left(5^{\prime}-\right.$ CTCGTAGTACATAAAATCAA-3') and 990-968R (5'-ATAAGGGGGAAAAATAAGAA-3') and reaction conditions given in Polziehn and Strobeck (1998). The PCR and sequencing were conducted by the University of Washington High-Throughput Genomics Center, Department of Genome Sciences (Seattle, Washington). Each 100-mL PCR was performed on a 9600 Perkin-Elmer Cetus Thermocycler using the following conditions: a 3min denaturing step at $94^{\circ} \mathrm{C} ; 30$ cycles at $94^{\circ} \mathrm{C}$ for $15 \mathrm{~s}$, $56^{\circ} \mathrm{C}$ for $30 \mathrm{~s}$, and $72{ }^{\circ} \mathrm{C}$ for $30 \mathrm{~s}$.

We conducted forward and reverse strand sequencing on all samples to ensure data quality. We performed each

Table 2. Data for eight elk (Cervus elaphus) populations in the Greater Yellowstone Ecosystem collected between the years of 2005 and 2008, including spatial coordinates, number of samples, years sampled, number of mtDNA haplotypes, and two genetic diversity estimates. All coordinates are in the Universal Transverse Mercator (UTM) NAD83 zone 12 projection. Population abbreviations are as follows: PV = Paradise Valley (Montana), MV = Madison Valley (Montana), NR = Northern Range (Yellowstone National Park), MF = Madison-Firehole (Yellowstone National Park), SR = Shoshone River (Wyoming), MC = Muddy Creek (Wyoming feeding ground), BC = Bench Corral (Wyoming feeding ground), and SC = Sand Creek (Idaho).

\begin{tabular}{lccccccc}
\hline Population & $\begin{array}{c}\text { UTM } \\
\text { (m East) }\end{array}$ & $\begin{array}{c}\text { UTM } \\
\text { (m North) }\end{array}$ & $\mathbf{n}$ & $\begin{array}{c}\text { Years } \\
\text { sampled }\end{array}$ & $\begin{array}{c}\text { Haplotypes } \\
\text { (No. of) }\end{array}$ & $\begin{array}{c}\text { Haplotype } \\
\text { diversity (SE) }\end{array}$ & $\begin{array}{c}\text { Nucleotide } \\
\text { diversity (SE) }\end{array}$ \\
\hline PV & 526045 & 5029408 & 61 & $2006-2008$ & 16 & $0.889(0.022)$ & $0.0059(0.003)$ \\
MV & 453908 & 4995027 & 80 & $2005-2007$ & 17 & $0.848(0.031)$ & $0.0055(0.003)$ \\
NR & 536585 & 4979966 & 44 & 2006 & 15 & $0.831(0.049)$ & $0.0049(0.002)$ \\
\hline MF & 495338 & 4945231 & 42 & 2007 & 12 & $0.858(0.035)$ & $0.0049(0.002)$ \\
SR & 608769 & 4925150 & 59 & 2007 & 15 & $0.835(0.036)$ & $0.0056(0.003)$ \\
MC & 634277 & 4721083 & 62 & 2005,2008 & 12 & $0.746(0.049)$ & $0.0035(0.002)$ \\
BC & 569692 & 4730309 & 13 & 2008 & 7 & $0.871(0.067)$ & $0.0045(0.002)$ \\
SC & 439437 & 4845368 & 19 & 2008 & 10 & $0.906(0.040)$ & $0.0059(0.003)$ \\
\hline
\end{tabular}


sequencing reaction using approximately $8 \mu \mathrm{L}$ of PCR product, as described in the Perkin-Elmer Dye Terminator Cycle Sequencing Ready Reaction kit. Cycle sequencing reaction parameters on a 9600 Perkin Elmer Cetus Thermocycler were as follows: denaturation at $96^{\circ} \mathrm{C}$ for $15 \mathrm{~s}$, annealing at $50^{\circ} \mathrm{C}$ to for $1 \mathrm{~s}$, and extension at $60^{\circ} \mathrm{C}$ for $4 \mathrm{~min}$. We separated sequencing reactions by electrophoresis on an ABI Prism 377 Perkin Elmer automated sequencer. The sequin file for the $380 \mathrm{mtDNA}$ sequences can be found in GenBank and Dryad (accession numbers: JX125702 - JX126108; see Archived Material).

We corrected and aligned sequences of mtDNA using DNAstar 5.0 software package (DNASTAR Inc., Madison, Wisconsin). We double-checked sequences visually for quality and correctness, including every polymorphic site. We randomly re-extracted and resequenced $5 \%$ of all samples to monitor for potential errors; we found none. Amplification and sequencing success was relatively high even for fecal samples, where $\sim 85 \%$ of samples yielded useable sequences, considering the relatively long mtDNA fragment we amplified (596 base pairs).

We genotyped eight microsatellite loci for three populations: Muddy Creek, Northern Range, and Paradise Valley (Figure 1; see Archived Material), using the same individuals for both microsatellites and mtDNA sequencing from the Muddy Creek and Northern Range populations. The Paradise Valley samples for mtDNA were from hunter-killed elk, whereas microsatellite DNA samples were from live captured elk in the same geographical location. The captured elk provided better quality DNA from fresh blood, which typically yields more reliable microsatellite genotypes than hunter-killed samples and which we obtained after the mtDNA sequences. We used the following microsatellite DNA loci: BM5004, BM888, BM1009, BM4208, FCB193, OarkP6, RM006, BM415 (Buchanan and Crawford 1992; Kossarek et al. 1993; Bishop et al. 1994; Paterson and Crawford 2000).

All microsatellite PCRs consisted of an initial denaturation at $96^{\circ} \mathrm{C}$ for $15 \mathrm{~s}$, annealing at 50 to $56^{\circ} \mathrm{C}$ (Table 1) for $1 \mathrm{~s}$, and extension at $60^{\circ} \mathrm{C}$ for $4 \mathrm{~min}$. We amplified the BM5004, BM888, and BM1009 loci together in one PCR; the BM4208 and FCB193 loci together in another (separate) PCR; and OarkP6 and RM006 in a third PCR. We amplified the BM415 locus alone at $50^{\circ} \mathrm{C}$ (Table 1). We extracted whole genomic DNA from elk tissue and blood samples using the QIAGEN Dneasy Tissue Kit (Qiagen) according to manufacturer's instructions. The reaction volume $(10 \mu \mathrm{l})$ contained $1.0 \mu \mathrm{L}$ DNA, $1 \times$ reaction buffer (Applied Biosystems, Foster City, California), $2.0 \mathrm{mM} \mathrm{MgCl}, 200 \mu \mathrm{M}$ of each dNTP, $1 \mu \mathrm{M}$ reverse primer, $1 \mu \mathrm{M}$ dye-labeled forward primer, $1.5 \mathrm{mg} / \mathrm{ml}$ bovine serum albumin, and $1 \mathrm{U}$ Taq polymerase (Applied Biosystems). We visualized the resultant products (PCR profiles) on a LI-COR DNA analyzer (LI-COR Biotechnology, Lincoln, Nebraska) and called genotypes visually (manually). We independently visualized and doublechecked the profiles and genotypes for quality and correctness. We randomly re-extracted and regenotyped
$5 \%$ of all samples to test for potential errors and found none.

We computed diversity indices (haplotype diversity and nucleotide diversity for each population), number of variable nucleotide sites, average number of haplotype differences, population pairwise $F_{S T}$ values, and a global $F_{S T}$ value using Arlequin 3.5 (Excoffier and Lischer 2010) and confirmed these values by GenAlEx 6.5 (Peakall and Smouse 2012). All $F_{S T}$ values considered only the differences in haplotype frequencies using 10,000 permutations to test for statistical significance (i.e., to test if $F_{S T}>0.0$ ). We used the Mantel test (Mantel 1967) to evaluate correlations between genetic distances (population pairwise $F_{S T}$ values) and pairwise geographic distances (Euclidean distance) between sample populations. We tested for isolation by distance in maternal genetic structure using the R package "vegan" using 10,000 permutations to test for significance (Oksanen et al. 2013). We also tested for isolation by distance expressed as $F_{S T} /\left(1-F_{S T}\right)$ against the natural logtransformed Euclidean distance (Rousset 1997).

For microsatellite data, we used Arlequin 3.5 to calculate pairwise and total $F_{S T}$ weight averaged over all loci (using analysis of molecular variance tests and 10,000 permutations for significance and 10,000 replicates for confidence intervals bootstrapped over loci). We calculated per-population-based measures of allelic richness, observed and expected heterozygosity, deviation from Hardy-Weinberg proportions $\left(F_{I S}\right)$, and linkage disequilibrium. We double-checked all values for microsatellites and confirmed them in GenAlEx 6.5.

We calculated the expected male to female gene flow ratio using a recently derived equation $7(\mathrm{c})$ in Hedrick et al. (2013):

$$
\frac{m_{m}}{m_{f}}=\frac{\left(1-F_{S T}\right) F_{S T(f)}-2 F_{S T}\left(1-F_{S T(f)}\right)}{2 F_{S T}\left(1-F_{S T(f)}\right)}
$$

In equation (1), $m_{m}$ is male gene flow and $m_{f}$ is female gene flow, $F_{S T}$ is measured overall genetic differentiation for a population (considering both male and female gene flow), and $F_{S T(f)}$ is the measured genetic differentiation for females in a population using maternally inherited mtDNA markers. Using equation (1), we calculated the ratio of male to female gene flow using global $F_{S T}$ values calculated for elk populations in the GYE. These estimates of gene flow assume an island model of gene flow, with assumptions that may be violated in some populations. Thus, only relative levels of gene flow can be roughly approximated (Whitlock and McCauley 1999).

Hedrick (2005) and Jost (2008) noted the tendency of $F_{S T}$ to be lower than expected for populations with high gene diversity (or high heterozygosity). Therefore, as an alternative analysis of male vs. female gene flow, we also computed the standardized genetic differentiation measure $G^{\prime \prime}{ }_{S T}$ to remove potential bias due to relatively high haplotype (gene) diversity for mtDNA (Meirmans and Hedrick 2011). We used the SMOGD program to calculate the value of global maternal gene flow ( $G^{\prime \prime}{ }_{S T(f)}$; Crawford 
2010). Confidence intervals are often calculated from bootstrapping over loci in programs such as GenAIEx and Arlequin. However, because mtDNA is treated as a single locus, bootstrapping for mtDNA (single locus) is not available in most genetic programs (Fstat, Arlequin, Genepop, GenAlex, etc.). Instead, we calculated confidence intervals for mtDNA by bootstrapping over individuals. This method of bootstrapping is available in the SMOGD program (which does not provide an $F_{S T}$ calculation). For microsatellites, we calculated the value for global $G^{\prime \prime}{ }_{S T}$ in GenAlEx 6.5 (we arrived at confidence intervals at by bootstrapping over loci). Both programs SMOGD and GenAIEx 6.5 provided nearly identical estimates of both global values of $G_{S T}^{\prime \prime}$. This analysis assumed that $G^{\prime \prime}{ }_{S T}$ can replace $F_{S T}$ in equation (1) (since $G^{\prime \prime}{ }_{S T}$ is an analog of the original $F_{S T}$ ), which Hedrick et al. (2013) point out might be more useful. However, Hedrick et al. (2013) also recommend that $G_{S T}^{\prime \prime}$ should be investigated theoretically (as they did for $F_{S T}$ ) to ensure it is appropriate to use $G^{\prime \prime}{ }_{S T}$ in equation (1).

\section{Results}

For mtDNA, haplotype diversity (gene diversity) ranged between 0.75 and 0.91 with an average of 0.85 , and 13.0 haplotypes per population. The total number of variable mtDNA nucleotide sites was 27, which defined 30 haplotypes (Table 2). Most substitutions were transitions except for one transversion, which is typical for mammals, including ungulates (e.g., Luikart et al. 2001). The average number of differences between haplotypes was 3.0 nucleotide sites and the mean number of variable sites within populations was 14.6.

For mtDNA, the global $F_{S T(f)}$ was $0.161(P=0.001)$. Pairwise $F_{S T}$ between populations ranged between 0.103 and $0.213(P<0.001$ for all pairwise comparisons, Table 3). Temporal $F_{\mathrm{ST}}$ values were zero. We found no significant correlation between geographic distance and mtDNA genetic population pairwise distances $(r=0.274$, $P=0.168$ ). Similarly, a second Mantel test using the relationship of $F_{S T} /\left(1-F_{S T}\right)$ against the natural logtransformed Euclidean distance was not significant $(r=$ $0.202, P=0.228$ ). Thus, there was no evidence of geographic isolation by distance among populations.

For microsatellite loci, mean heterozygosity ranged between 0.56 and 0.62 for the study populations, with an average allelic richness of 3.88 (Table 4). Populations and loci were all in or near Hardy-Weinberg proportions, with no significant gametic disequilibrium. The global $F_{S T}$ from microsatellites was 0.002 (95\% Cl: $0.000-0.011 ; P=$ 0.332 ) when averaged across loci (Table 5). The estimated ratio of male to female gene flow was $m_{m} / m_{f}=46$ using our global $F_{S T}$ values derived from mtDNA $\left(F_{S T(f)}=\right.$ $0.161)$ and from microsatellites $\left(F_{S T}=0.002\right)$ in equation 1. Global maternal $G^{\prime \prime}{ }_{S T(f)}$ for mtDNA was equal to 0.277 (95\% Cl: 0.153-0.430). For microsatellites the global $G^{\prime \prime}{ }_{S T}$ was 0.005 (95\% Cl: $0.000-0.030 ; P=0.331)$. We again calculated the ratio of male to female gene flow and found it to be $m_{m} / m_{f}=37$, which was still high but nonetheless lower than the $m_{m} / m_{f}=46$ produced from using $F_{S T}$ values.
Table 3. Pairwise genetic differentiation $\left(F_{S T}\right)$ estimates for the eight elk (Cervus elaphus) populations in the Greater Yellowstone Ecosystem for mitochondrial DNA from samples collected between the years of 2005 and 2008. All $F_{S T}$ values were significantly greater than zero. Population abbreviations are as follows: PV = Paradise Valley (Montana), MV = Madison Valley (Montana), NR = Northern Range (Yellowstone National Park), MF = Madison-Firehole (Yellowstone National Park), SR = Shoshone River (Wyoming), MC = Muddy Creek (Wyoming feeding ground), $\mathrm{BC}=$ Bench Corral (Wyoming feeding ground), and SC = Sand Creek (Idaho).

\begin{tabular}{lcccccccc}
\hline & PV & MV & NR & MF & SR & MC & BC & SC \\
\hline PV & - & & & & & & & \\
MV & 0.132 & - & & & & & & \\
NR & 0.139 & 0.160 & - & & & & & \\
MF & 0.126 & 0.147 & 0.155 & - & & & & \\
SR & 0.138 & 0.158 & 0.167 & 0.154 & - & & & \\
MC & 0.183 & 0.201 & 0.213 & 0.200 & 0.210 & - & & \\
BC & 0.118 & 0.142 & 0.151 & 0.136 & 0.149 & 0.203 & - & \\
SC & 0.103 & 0.126 & 0.134 & 0.119 & 0.133 & 0.184 & 0.110 & - \\
\hline
\end{tabular}

\section{Discussion}

Elk in the GYE had a high ratio of male to female gene flow compared to findings for other large mammals in the literature, including some species in the same taxonomic family and genus (Table 6). The global $F_{S T(f)}$ we computed for mtDNA was 81 times larger than the global $F_{S T}$ value for microsatellites, which yielded an estimated rate of gene flow that was 46 times higher for male elk than for female elk in the GYE. Similarly, the results from $G^{\prime \prime}{ }_{S T}$ (an analog of $F_{S T}$ ) also suggested malebiased gene flow with 37 times higher male-mediated gene flow and with nonoverlapping confidence intervals for $G_{S T}^{\prime \prime}$ calculated from mtDNA and microsatellites. In comparison, red deer (Cervus elaphus) in the Scottish Highlands have gene flow for males that is 13 times higher than that for females (Table 6; Pérez-Espona et al. 2009, 2010). Also, Yellowstone bison (Bison bison), present in the same geographical region as our elk, have a moderately high ratio of male to female gene flow of 5 (Halbert et al. 2012).

These comparisons highlight the rather high malebiased gene flow in GYE elk compared to other ungulate species known or suspected to exhibit male-biased dispersal and female natal philopatry (when females return to their birthplace to breed). In this context, dispersal is defined as the movement of individuals from their place of birth to a spatially discrete or distant population, with permanent or long-term settlement for the purpose of breeding (Lowe and Allendorf 2010). Similar to our microsatellite data, Hicks et al. (2007) also report low $F_{S T}$ values for elk microsatellites $\left(F_{S T}=0.004\right.$; $P=0.281$ ) genotyped from tissue samples from the northern and southern portions of the GYE. Their study used five of the same microsatellite markers (BM5004, $B M 888, B M 4208, F C B 193$, and $B M 415)$ and samples from a similar geographic area $(\sim 260 \mathrm{~km}$ between the Hicks 
Table 4. Characteristics of microsatellite variation from three elk (Cervus elaphus) populations using eight loci from samples collected between the years of 2005 and 2008. Values include the number of samples per population, allelic richness, observed and expected heterozygosity, and deviation from Hardy-Weinberg proportions $\left(F_{\mathrm{IS}}\right)$. Population abbreviations are as follows: PV $=$ Paradise Valley (Montana), MC = Muddy Creek (Wyoming feeding ground), and NR = Northern Range (Yellowstone National Park).

\begin{tabular}{lccccrr}
\hline Population & $\boldsymbol{n}$ & $\begin{array}{c}\text { Allelic } \\
\text { richness (SE) }\end{array}$ & $\begin{array}{c}\text { Observed } \\
\text { heterozygosity (SE) }\end{array}$ & $\begin{array}{c}\text { Expected } \\
\text { heterozygosity (SE) }\end{array}$ & $\boldsymbol{F}_{\text {IS }}(\boldsymbol{P}$ value) \\
\hline NR & 20 & $3.75(0.491)$ & $0.617(0.027)$ & $0.569(0.038)$ & $-0.096(0.933)$ \\
PV & 20 & $4.13(0.693)$ & $0.556(0.056)$ & $0.596(0.033)$ & $0.059(0.221)$ \\
MC & 19 & $3.75(0.313)$ & $0.578(0.064)$ & $0.567(0.042)$ & $-0.048(0.762)$ \\
\hline
\end{tabular}

et al. [2007] study populations as compared to $\sim 300 \mathrm{~km}$ between our Paradise Valley and Muddy Creek populations from the northern and southern GYE, respectively; Figure 1).

Gene flow estimates from equation 1 assume equal effective population sizes $\left(N_{\mathrm{e}}\right.$; or equal variance in reproductive success) for males and females. However, high variance in male reproductive success can reduce local $N_{\mathrm{e}}$ for microsatellite loci (without reducing $N_{\mathrm{e}}$ for mtDNA) and result in higher local genetic drift and thus higher $F_{S T}$ for microsatellites compared to mtDNA (Hedrick et al. 2013). For example, if only $20 \%$ of males reproduce (e.g., due to only a few males dominating reproduction), then the local $N_{\mathrm{e}}$ (for microsatellites) is reduced by approximately 50\% (Allendorf et al. 2013: figure 7.3), and the global $F_{S T}$ for microsatellites roughly doubles from the value expected with random male reproductive success. In other words, if there is high variance in male reproductive success for elk, which likely exists given male dominance and harems, then the expected difference between $F_{S T}$ values for mtDNA vs. microsatellites would be smaller (all else being equal) because of the relatively reduced local $N_{\mathrm{e}}$ (and higher expected $F_{S T}$ ) for microsatellites. The likely reduced male $N_{\mathrm{e}}$ (compared to females) suggests that an even greater magnitude of male-biased gene flow (than reported here) is needed to explain the much lower $F_{S T}$ observed for microsatellites compared to mtDNA.

Female gene flow (or genetic structure) was not significantly correlated ( $r=0.274, P=0.168)$ with the straight (Euclidian) geographic distance between populations. The lack of correlation between geographic and genetic distance was best illustrated by populations that

Table 5. Pairwise genetic differentiation estimates $\left(F_{S T}\right)$ for three elk (Cervus elaphus) populations in the Greater Yellowstone Ecosystem using eight microsatellite loci from samples collected between the years of 2005 and 2008. All $P$ values are in parentheses and are nonsignificant. Population abbreviations are as follows: PV = Paradise Valley (Montana), $\mathrm{MC}=$ Muddy Creek (Wyoming feeding ground), and NR = Northern Range (Yellowstone National Park).

\begin{tabular}{lccc}
\hline & PV & MC & NR \\
\hline PV & - & & \\
MC & $0.011(0.120)$ & - & - \\
NR & $0.000(0.907)$ & $0.004(0.297)$ & - \\
\hline
\end{tabular}

have high pairwise $F_{S T}$ values, but are located close together geographically. For example, Muddy Creek and Bench Corral were separated by a relatively small geographic distance $(\sim 65 \mathrm{~km})$, but have one of the largest pairwise genetic distances $\left(F_{S T}=0.203\right.$; Figure 1). The lack of isolation by geographic distance raised the hypothesis that behavioral factors (e.g., seasonal patterns of migration) or landscape features might be more important in explaining female gene flow patterns than geographic (Euclidian) distance.

In summary, maternal gene flow among elk populations in the GYE was low compared to male gene flow, which resulted in high sex-biased gene flow estimates compared to other large mammals. The low female gene flow over distances of 50 to $325 \mathrm{~km}$ was an intriguing result for such a (potentially) highly mobile species. Future studies should use many additional populations and apply a landscape genetics approach to test for effects of landscape features on female gene flow because simple geographic (Euclidean) distance did not explain maternal genetic differentiation. The growing availability of genetic data to compare relative male to female gene flow provides many exciting opportunities to explore the magnitude, causes, and implications of sex-biased gene flow likely to occur in many species.

Table 6. Estimated ratio of male vs. female gene flow $\left(m_{m} /\right.$ $\left.m_{f}\right)$ for studies involving large mammal species calculated using equation 7(c) in Hedrick et al. (2013). Values given are the global values of $F_{S T}$ from microsatellites (considering both male and female gene flow), gene flow related to mitochondrial DNA $\left(F_{S T[f]}\right)$, and the reference publication reporting $F_{S T}$ values used for each set of calculations. Reference populations are for Greater Yellowstone Ecosystem (GYE) elk (Cervus elaphus), Yellowstone bison (Bison bison), Scottish Highland red deer (Cervus elaphus), and western Canadian white-tailed deer (Odocoileus virginianus).

\begin{tabular}{|c|c|c|c|}
\hline Species & $F_{S T}$ & $F_{S T(f)}$ & $m_{m} / m_{f}$ \\
\hline (GYE) elk & 0.002 & 0.161 & 45.9 \\
\hline Yellowstone bison ${ }^{a}$ & 0.032 & 0.292 & 5.25 \\
\hline Highland red deer ${ }^{b}$ & 0.020 & 0.358 & 12.7 \\
\hline Canadian white-tailed deer ${ }^{c}$ & 0.006 & 0.015 & 0.26 \\
\hline
\end{tabular}




\section{Archived Material}

Please note: The Journal of Fish and Wildlife Management is not responsible for the content or functionality of any archived material. Queries should be directed to the corresponding author for the article.

To cite this archived material, please cite both the journal article (formatting found in the Abstract section of this article) and the following recommended format for the archived material.

Data A1. 2013-12-16_mtDNA_8pops. Arlequin (v3.5) formatted file for elk (Cervus elaphus) in Greater Yellowstone National Park. File includes raw mtDNA sequences, sampled between the years of 2005 and 2008, with 596 base pairs for 380 elk from eight populations.

Found at DOl: http://dx.doi.org/doi:10.5061/dryad. $8 \mathrm{~g} 118$

Data A2. 2013-12-16_Microsats_3pops. Genepop formatted file for elk in the Greater Yellowstone Ecosystem. File contains nuclear microsatellite DNA for eight loci genotyped in 59 elk in three populations sampled between the years of 2005 and 2008 .

Found at DOI: http://dx.doi.org/doi:10.5061/dryad.8g118

\section{Acknowledgments}

The University of Washington High Throughput Sequencing Center (HTSeq) provided mtDNA sequencing, and K. Pilgrim helped isolate DNA and genotype microsatellites. Fred W. Allendorf provided helpful comments on an earlier version of this paper. Peter Smouse provided helpful advice on interpreting measures of genetic differentiation and computing confidence intervals. Two anonymous reviewers and the Subject Editor provided helpful reviews and comments. National Science Foundation grants supported GL and PC (DEB-0723928, DEB-1258203, DEB-1067613), BKH and MK (DGE-0504628, and RAG DEB-0716188). GL was also supported by grants from the US National Park Service (USA) and a grant (PTDC/BIA-BDE/65625/2006) from the Portuguese Science Foundation (FCT). ADM and MJK were supported by grants from the Wyoming Game and Fish Department, the Rocky Mountain Elk Foundation, the Wyoming Animal Damage Management Board, and the Wyoming Governor's Big Game License Coalition.

Any use of trade, product, or firm names is for descriptive purposes only and does not imply endorsement by the U.S. Government.

\section{References}

Allendorf FW, Luikart G, Aitken SN. 2013. Conservation and the genetics of populations. Malden, Massachusetts: Wiley-Blackwell.

Bishop MD, Kappesj SM, Keele W, Stone RT, Sundeng SLF, Hawkins A, Toldor SS, Fries, Groszj Y, Beattie CW. 1994. A genetic linkage map for cattle. Genetics 136:619-639.

Boyce MS, Hayden-Wing LD. 1979. North American elk: ecology, behavior and management. Laramie, Wyoming: University of Wyoming.
Buchanan FC, Crawford AM. 1992. Molecular genetic markers: ovine microsatellites at the OarFCB11, OarFCB128, OarFCB193, OarFCB266 and OarFCB304 loci. Animal Genetics 24:145.

Crawford NG. 2010. SMOGD: software for the measurement of genetic diversity. Molecular Ecology Resources 10:556-557.

Cullingham $\mathrm{Cl}$, Merrill EH, Pybus MJ, Bollinger TK, Wilson GA, Coltman DW. 2011. Broad and fine-scale genetic analysis of white-tailed deer populations: estimating the relative risk of chronic wasting disease spread. Evolutionary Applications 1:116-131.

Excoffier L, Lischer HEL. 2010. Arlequin suite ver. 3.5: a new series of programs to perform population genetics analyses under Linux and Windows. Molecular Ecology Resources 10:564-567.

Halbert ND, Gogan PJP, Hedrick PW, Wahl L, Derr JN. 2012. Genetic population substructure in bison in Yellowstone National Park. Journal of Heredity 103:360-370.

Hedrick PW. 2005. A standardized genetic differentiation measure. Evolution 59:1633-1638.

Hedrick PW, Allendorf FW, Baker CS. 2013. Estimation of male gene flow from measures of nuclear and female genetic differentiation. Journal of Heredity 104:713717.

Hicks JF, Rachlow JL, Rhodes OE, Williams CL, Waits LP. 2007. Reintroduction and genetic structure: Rocky Mountain elk in Yellowstone and the western states. Journal of Mammalogy 88:129-138.

Houston DB. 1974. The northern elk: ecology and management. New York: Macmillan.

Jost L. 2008. GST and its relatives do not measure differentiation. Molecular Ecology 17:4015-4026.

Kossarek LM, Grosse WM, Finlay O, Mcgraw RA. 1993. Rapid communication: bovine dinucleotide repeat polymorphisms RM006. Journal of Animal Science 71:3176.

Lowe WH, Allendorf FW. 2010. What can genetics tell us about population connectivity? Molecular Ecology 19: 3038-3051.

Luikart GL, Gielly L, Excoffier JD, Vigne J, Bouvet, Taberlet P. 2001. Multiple maternal origins and weak phylogeographic structure in domestic goats. Proceedings of the National Academy of Sciences of the United States of America 98:5927-5930.

Mantel N. 1967. The detection of disease clustering and a generalized regression approach. Cancer Research 27: 209-220.

Martin K, Stacey PB, Braun CE. 2000. Recruitment, dispersal, and demographic rescue in spatially-structured white-tailed ptarmigan populations. The Condor 102:503-516.

Maudet C, Luikart G, Durray D, Von Hardensberg A, Taberlet P. 2004. Low genotyping error rates in wild ungulate feces sampled in winter. Molecular Ecology Notes 4:772-775.

Meirmans PG, Hedrick PW. 2011. Assessing population structure: $F(S T)$ and related measures. Molecular Ecology Resources 11:5-18. 
Oksanen J, Blanchet FG, Kindt R, Legendre P, Minchin PR, O'Hara RB, Simpson GL, Solymos P, Stevens MHH, Wagner H. 2013. Vegan: community ecology package. $\mathrm{R}$ package version 2.0-7. Available: http://CRAN.Rproject.org/package = vegan (January 2014).

Paterson KA, Crawford AM. 2000. Ovine microsatellite OarkP6 isolated from a BAC containing the ovine interferon gamma gene. Animal Genetics 31:343.

Peakall R, Smouse PE. 2012. GenAIEx 6.5: genetic analysis in Excel. Population genetic software for teaching and research-an update. Bioinformatics 28:2537-2539.

Pérez-Espona S, Pérez-Barbería FJ, Goodall-Copestake WP, Jiggins CD, Gordon IJ, Pemberton JM. 2009. Genetic diversity and population structure of Scottish Highland red deer (Cervus elaphus) populations: a mitochondrial survey. Heredity 102:199-210.

Pérez-Espona S, Pérez-Barbería FJ, Jiggins CD, Gordon IJ, Pemberton JM. 2010. Variable extent of sex-biased dispersal in a strongly polygynous mammal. Molecular Ecology 19: 3101-13.

Polziehn RO, Strobeck C. 1998. Phylogeny of wapiti, red deer, sika deer, and other North American cervids as determined from mitochondrial DNA. Molecular Phylogenetics and Evolution 10:249-258.

Rousset F. 1997. Genetic differentiation and estimation of gene flow from F-statistics under isolation by distance. Genetics 145:1219-1228.

Tallmon DA, Luikart G, Waples RS. 2004. The alluring simplicity and complex reality of genetic rescue. Trends in Ecology and Evolution 19:489-496.

Thorne ET, Morton JK, Ray WC. 1979. Brucellosis, its effect and impact on elk in western Wyoming. Pages 212220 in Boyce MS, Hayden-Wing LD, editors. North American elk: ecology, behavior and management. Laramie, Wyoming: University of Wyoming.

Toweill DE, Thomas JW, McCabe RE. 2002. North American elk: ecology and management. Washington, District of Columbia: Smithsonian Institution Press.

Whitlock MC, McCauley DE. 1999. Indirect measures of gene flow and migration: FST $\neq 1 /(4 \mathrm{Nm}+1)$. Heredity 82:117-125.

Wright S. 1943. Isolation by distance. Genetics 28:114-128.

Wright S. 1951. The genetical structure of populations. Annals of Eugenics 15:323-354. 